\title{
Energy assessment of wood-frame vertical envelope solutions applied in educational establishments of southern Chile
}

\author{
Evaluación energética de soluciones de envolvente vertical aplicadas en establecimientos \\ educacionales de la zona Austral de Chile
}

Jeremy Piggot (Main and Corresponding author)

Universidad del Bío-bío, Departamento de Diseño y Teoría de la Arquitectura

Collao 1202, Concepción (Chile)

jpiggot@ubiobio.cl

\section{María Beatriz Piderit}

Universidad del Bío-bío, Departamento de Diseño y Teoría de la Arquitectura

Collao 1202, Concepción (Chile)

mpiderit@ubiobio.cl

\section{Pierre Blanchet}

Université Laval, Wood and Forestry Science Department

2425, rue de la Terrasse, Quebec (Canada)

pierre.blanchet@sbf.ulaval.ca

Manuscript Code: 1191

Date of Acceptance/Reception: 14.03.2019/18.10.2018

DOI: 10.7764/RDLC.18.1.201

\section{Abstract}

The objective of this research is to analyze the thermal performance of wood-frame vertical envelope solutions used in Canadian establishments and to evaluate how these technologies contribute towards reducing the energy demand of educational establishments in Chile. The first stage of the research involved reviewing the wood-frame envelope solutions used in Canada. Six solutions were selected in order to evaluate their thermal performance and the energy demand reduction produced when they are incorporated in Chilean educational establishment envelopes. To improve the accuracy of the energy demand results, the linear thermal transmittance values $(\Psi)$ were obtained for each of the wall solution joints with the rest of the envelope's elements, using LBNL Therm. Finally, using DesignBuilder, energy simulations were developed incorporating all the values ( $\Psi$ ) obtained before, in order to evaluate the demand reduction produced by the selected solutions. The results indicate that the solutions analyzed save up to $51 \%$ of the heating demand of the establishments during the coldest months. This allows promoting the use of wood as a sustainable material which aligns with the "Energy 2050" policy.

Keywords: Energy Assessment, Vertical Wood-Frame Envelope, Educational Establishments.

\section{Resumen}

El objetivo de esta investigación es analizar el desempeño térmico de soluciones de envolvente vertical de tabiquería de madera utilizadas en establecimientos Canadienses y evaluar cómo estas tecnologías contribuyen en la reducción de la demanda energética de establecimientos educacionales en Chile. La primera etapa de esta investigación estuvo relacionada con la revisión de los diferentes tipos de soluciones de tabiquería estructural utilizadas en Canadá. Seis soluciones se seleccionaron para así poder evaluar su desempeño térmico y la reducción en la demanda energética producida cuando estas se incorporan en la envolvente de establecimientos educacionales chilenos. Para mejorar la precisión de los resultados, se calcularon los valores de transmitancia térmica lineal $(\Psi)$ para cada una de las uniones de las soluciones de muro con el resto de los elementos de la envolvente, utilizando LBNL Therm. Finalmente, utilizando DesignBuilder, se realizaron simulaciones energéticas incorporando todos los valores de transmitancia lineal $(\Psi)$ obtenidos de manera previa para así evaluar la reducción de la demanda energética producida por las soluciones seleccionadas. Los resultados muestran que las soluciones analizadas generan ahorros de hasta un 51\% de la demanda de calefacción del establecimiento en los meses más fríos del año. Esto permite promover la madera como un material sustentable que se alinea con lo mencionado en la política "Energía 2050"

Palabras clave: Evaluación energética, Envolvente vertical de tabiquería, Establecimientos educacionales.

Introduction

This article presents the results of bilateral research between Canada and Chile, whose goal is to analyze wood-frame vertical envelope solutions used as the main construction system in Canadian educational establishments in order to evaluate how these technologies contribute towards promoting the use of wood in Chilean educational establishments and other type of buildings. 
Educational establishments are presented to society as the tool that helps make the optimal progress of individuals' education possible, aiding the administration, transfer and promotion of knowledge (Okolie, 2011). These facilities play a fundamental role in the country's development and, in Chile; they are a means that provide tools to make the social advancement of people possible, improving their life quality while having a direct impact on reducing poverty indexes. However, the performance of young people and children, who spend around $70 \%$ of their time in these buildings, is directly affected by the comfort and well-being offered inside the learning spaces (Tookaloo \& Smith, 2015).

\section{Description of the problem}

In Chile, given its climatic diversity along with a deficient normative framework for environmental comfort in schools, there are serious environmental quality issues for educational spaces which result in an inadequate thermal and energy performance (Armijo, Whitman, \& Casals, 2011; Trebilcock, Soto, Figueroa, \& Piderit, 2016). This is accentuated in extreme climates like the country's southern area, where it is common that the thermal properties of building's construction elements do not avoid significant heat losses. There is a lack of solutions for thermal bridges and leaks, especially in wooden buildings (Bobadilla et al., 2014), resulting in a high heating demand (Nawawi \& Khalil, 2008). This demand is often met with heating systems that release great amounts of humidity and contaminants into the environment, systems like natural gas, paraffin and lumber (Adonis \& Gil, 2001). Thus, the indoor humidity levels and other elements exceed the recommended values (A.S.H.R.A.E, 2001; Mazzei, Minichiello, \& Palma, 2005), fostering the creation of allergenic organisms and pathogens which generate respiratory problems for the users (Beggs, 2010; Raizenne, Dales, \& Burnett, 1998).

\section{State of the art}

As part of the solution to avoid building high energy demand schools, countries like Canada, have been moving forward to integrate wood constructive solutions into the design of their envelopes. Research has indicated that this material is substantially more thermally efficient than steel, concrete or masonry in envelopes (Finch, Wang, \& Ricketts, n.d.). In addition, when well designed and built, it can exceed the fire safety and acoustic insulation demands (Burrows, 2006). There are also studies which demonstrate that using wood as the main construction material has a higher acceptability level thanks to some of its properties (Høibø, Hansen, \& Nybakk, 2015; Strobel, Nyrud, \& Bysheim, 2017).

It is worth highlighting that the design of the vertical envelope is the key factor to avoid heat loss in mid-rise buildings in cold climates, because its efficiency will have a considerable effect at an energy level (Kosny, Asiz, Smith, Shrestha, \& Fallahi, 2014). The Canadian construction industry knows wood's real efficient thermal properties and for this reason most of the residential and public sector in Canada is built incorporating wood as the main material, even in the coldest areas.

Using this as a base point, and bearing in mind that Chile has a high forestry production and the potential for wood construction, the aim is set to study if the vertical wood-frame envelope constructive solutions used in Canada will improve the thermal performance of educational establishments located in the South of Chile, and therefore their monthly energy demand be reduced significantly.

\section{Methodology}

In order to evaluate the improvement of thermal performance of educational establishments utilizing different envelope solutions, Energy Plus Dynamic Simulations is utilized, since this method is internationally validated and several studies utilize it (CITEC UBB, 2012a; Ko, Gosti, \& Kristl, 2018; Méndez, Capozzoli, Cascone, \& Sassone, 2015; Rodriguez-ubinas, Montero, Porteros, \& Vega, 2014; Rubeis, Nardi, Ambrosini, \& Paoletti, 2018; Torres-rivas, Palumbo, Haddad, Cabeza, \& Jiménez, 2018). The research methodology is divided in four stages. (a) Comparative analysis between Canada and Chile regarding the weather conditions that wood-frame envelopes must resist in climates with similar characteristics. The cities compared are Sandspit in Canada (Province of British Columbia) and Punta Arenas in Chile (Southern area). (b) Survey of vertical envelope construction solutions applied on educational buildings in Canada, checking that they have suitable thermal properties for the weather conditions of the areas being analyzed (Compliance of NBC of Canada and TDRe standards). (c) Thermal flow analysis using the LBNL Therm 7.0 software on each one of the six solutions selected plus a base solution which has similar structural properties. This makes it possible to determine the linear thermal transmittance values $(\Psi)$ and thus improve the accuracy of the energy dynamic simulation done subsequently in the next stage. (d) Analysis of the energy demand on the 3D model of a standard educational establishment located in the south of Chile, applying the studied envelopes, using the DesignBuilder 5.0.3.007 software 
(with Energy Plus as the simulation engine) and incorporating the linear thermal transmittance values of structural thermal bridges obtained in stage (c).

\section{Stage (a): Comparative climate analysis between Chile and Canada}

Figure 1 shows the temperature averages and the relative humidity percentages by month for the cities of Sandspit (Canada) and Punta Arenas (Chile). Sandspit is located in the Canadian climate zone "7a" mentioned in the National Energy Code for Buildings among other cities such as Toronto, Quebec City and Montreal (National Research Council of Canada, 2011); and Punta Arenas is located in the Chilean climate zone "8 SE" mentioned in the Chilean standard 1079 (Nch.1079) among other cities such as Castro, Coyhaique and Cochrane (Instituto Nacional de Normalización, 2008).

As can be seen, the monthly mean temperatures fall within similar ranges. In Sandspit, the temperature only tends to be slightly lower than Punta Arenas during the winter. Regarding the relative humidity in winter, most of the time it remains within similar percentages in an approximate range of between $75 \%$ and $90 \%$ for both cities throughout the year.

Figure 1. Temperature and humidity comparison diagram obtained using Climate Consultant. Source: Climate Consultant, using weather files in Energy Plus Weather format (.epw)
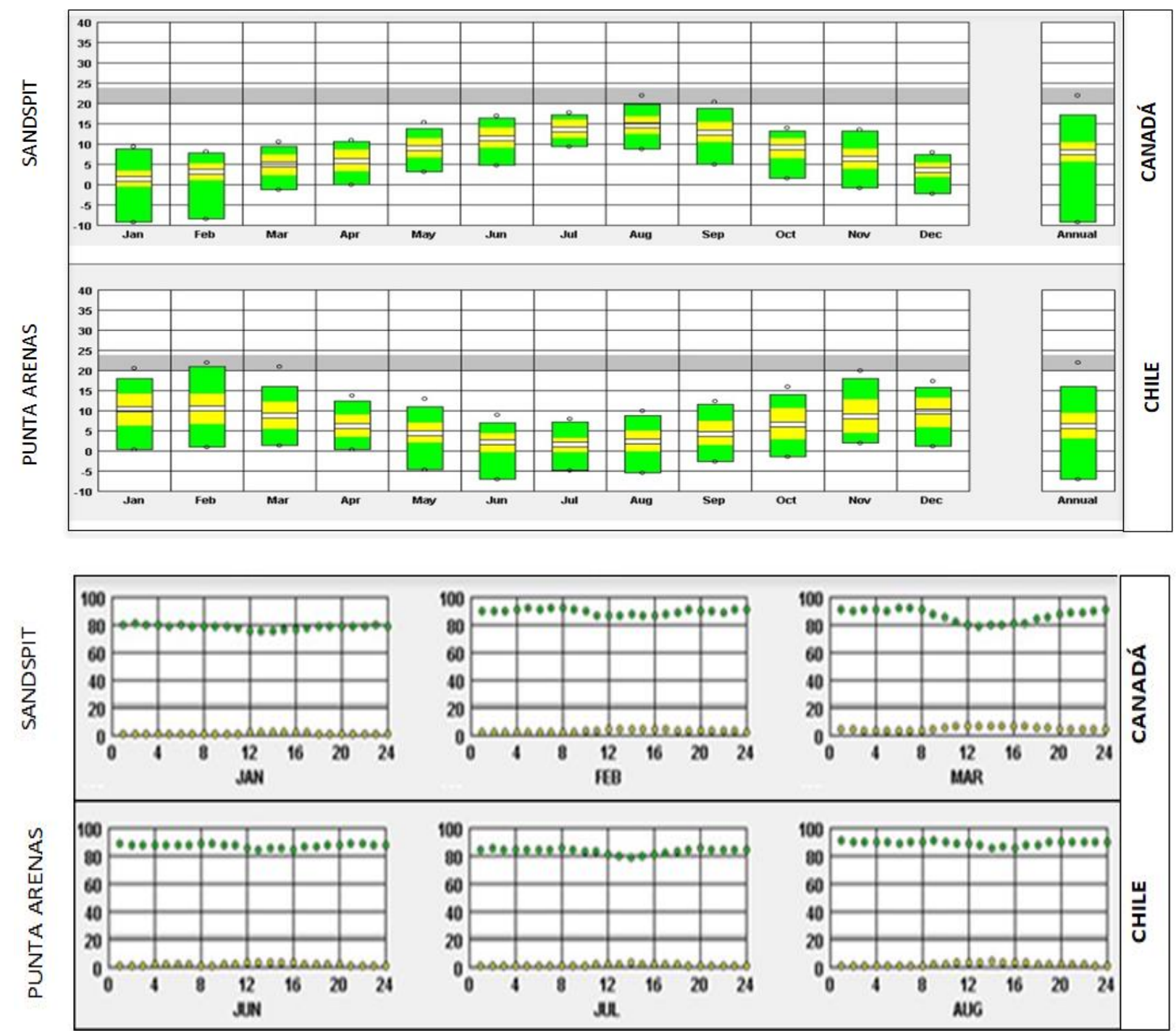

\section{Stage (b): Vertical wood-frame envelope solutions selected}

A revision was made of the wood-frame vertical envelopes used in educational establishments in Canada. Educational establishments of different areas of Canada were visited, choosing the commonly used solutions which have properties that are recognized as properly fitting Canadian weather conditions (Burrows, 2006; Finch et al., n.d.). The six 
construction solutions chosen, each of them classified with a number, are shown in Figure 2: 2"x 4" wood-frame with internal glass fiber insulation is the first selected solution (S1), 2"x 6" wood-frame with internal glass fiber insulation is the second solution (S2), 2"x 4" with continuous external 2" and 4" thick insulation are the third and fourth selected solutions (S3 and S4) and double wood-frame with continuous internal 2" and 4" thick insulation are the fifth and sixth solution ( $\mathrm{S} 5$ and $\mathrm{S6}$ ). The thermal qualities of the solutions are verified, checking that each one complies with the $U$ value standards mentioned in the National Building Code of Canada (NBC of Canada), for the Canadian weather zone "7a", which defines a U value of $0.36 \mathrm{Wm}^{2} \mathrm{~K}$ (National Research Council of Canada, 2012). It was also checked that they comply with the Chilean Standardized Terms of Reference (TDRe) for the climate zone " 8 SE" which defines a U value of $0.4 \mathrm{Wm}^{2} \mathrm{~K}$ (CITEC UBB, 2012b). All of the solutions complied.

\section{Stage (c): Thermal flow study of the envelope}

When analyzing the thermal performance of an envelope, the evaluation of the thermal bridge produced is necessary to obtain precise results, as these can cause clear heat losses (Muñoz \& Bobadilla, 2012) especially in wood-frame solutions, since on structures comprising wooden elements, the bridges of the joints are the ones which can generate the most significant losses at a heat transmission level (Tadeu, Simões, Simões, \& Prata, 2011). In this stage, a thermal flow study was performed in order to assess the occurrence of structural thermal bridges for each one of the six solutions, not only on the linear section of the wall, but also on the joints of the envelope's elements. The linear thermal transmittance values $(\Psi)$ were determined for each one of the joints between the walls and the different elements of a building's envelope (wall-wall, wall-frame, wall-mezzanine, wall-roof and wall-floor), using the LBNL Therm 7.0 software along with the calculation formulated and methodology mentioned in the ISO 10211 standard Thermal bridges in building construction - Heat flows and surface temperatures - Detailed calculations (International Organization for Standardization, 2017) (Equation 1). These values $(\Psi)$ have two purposes for this study. First, they represent the difference between the thermally interrupted element and the uninterrupted component indicating the magnitude of the thermal bridge generated on each joint, allowing a comparison to be made between the 6 solutions and the base solution. Second, they can be included in the energy dynamic simulations which are made afterwards with the DesignBuilder software in order to improve the accuracy of the results.

Equation 1. Calculation of linear thermal transmittance. (Source: I.S.O 10211).

$$
\begin{aligned}
& \Psi=l_{j} \cdot\left(U_{\text {factor }(T B)}-U_{\text {wall }}\right) \\
& \Psi=L^{2 D}-\Sigma\left(U_{j} \cdot l_{j}\right) \\
& L^{2 D}=U_{\text {factor }}(T B) \cdot l_{(T B)}
\end{aligned}
$$

Where,

$\Psi$ : Linear thermal transmittance of the thermal bridge

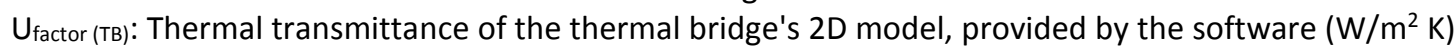

$U_{\text {wall }}$ Thermal transmittance of the constant flow section or linear element $\left(\mathrm{W} / \mathrm{m}^{2} \mathrm{~K}\right)$

$\mathrm{U}_{\mathrm{j}}$ : Weighted thermal transmittance of a standardized flow element, be this a wall, floor or roof $\left(\mathrm{W} / \mathrm{m}^{2} \mathrm{~K}\right)$

$\mathrm{l}_{\mathrm{j}}$ : Length of the 2D geometric model on which the $U j$ value is applied $(\mathrm{m})$

ᄂ(тв): Total length of the 2D model which incorporates the thermal bridge mentioned $(\mathrm{m})$

$\mathrm{L}^{2 \mathrm{D}}$ : Linear coupling coefficient obtained in the 2D model $(\mathrm{W} / \mathrm{m} \mathrm{K})$

To be able to compare the linear thermal transmittance $(\Psi)$ results with the Chilean context, the decision was made to use a base solution of the vertical wood-frame envelope used in Chile. It is for this reason that the solution coded 1.2.M.C25.8 - 2"x4" Structured wood wall with $60 \mathrm{~mm}$ thick internal glass wool from the Official List of Construction Solutions for Thermal Conditioning (Ministerio de Vivienda y Urbanismo, 2014) is chosen, since it is made of wood-frame and has a $U$ value of $0.595 \mathrm{~W} / \mathrm{m}^{2} \mathrm{~K}$ which is close to the $0.6 \mathrm{~W} / \mathrm{m}^{2} \mathrm{~K}$ required by the Chilean standard O.G.U.C for the climatic zone where most of Chile's southern area is located (Ministerio de Vivienda y Urbanismo, 2017). Furthermore, because of the elements which comprise it, its structural properties are comparable to the other wood-frame selected solutions. 
Figure 2. Vertical wood frame envelope solutions chosen (Source: Own preparation)

\begin{tabular}{l|l|} 
S1 & $\begin{array}{l}\text { 2"x4" Wood Frame } \\
\text { U VALUE : } 0.348 \mathrm{~W} / \mathrm{m}^{2} \mathrm{~K}\end{array}$ \\
\hline
\end{tabular}

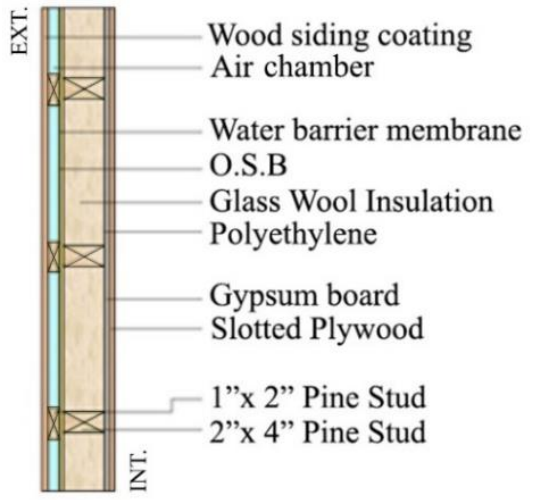

(PLAN VIEW)
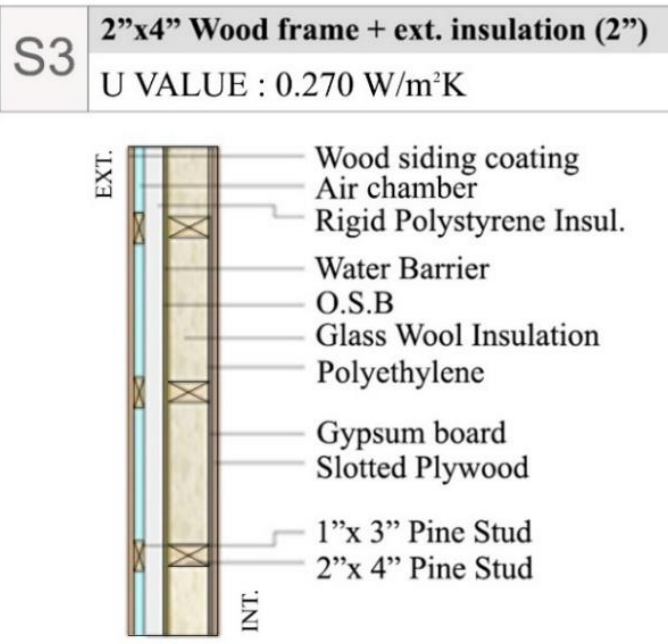

(PLAN VIEW)

\section{S5 Double frame + int. insulation (2") \\ U VALUE : $0.170 \mathrm{~W} / \mathrm{m}^{2} \mathrm{~K}$}

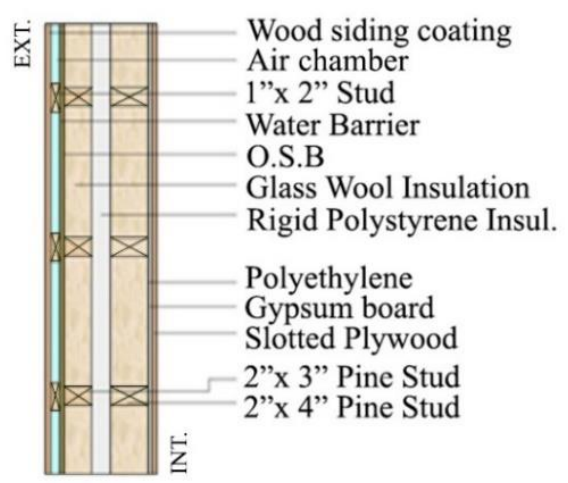

(PLAN VIEW)

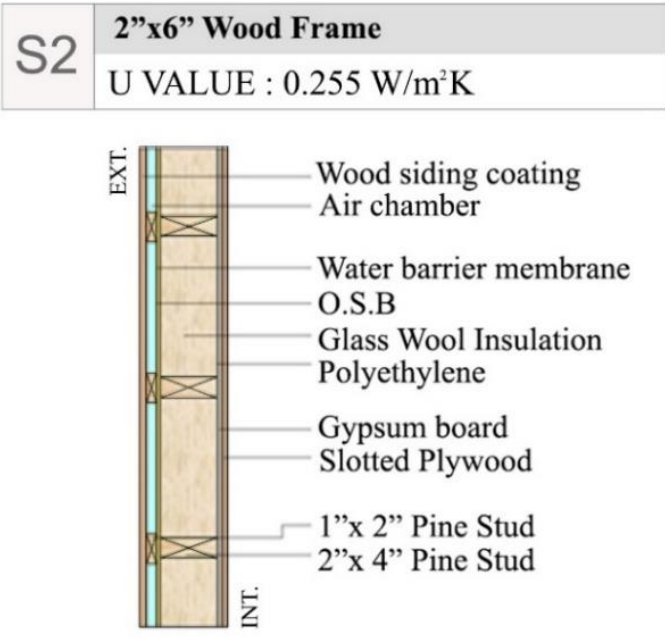

(PLAN VIEW)

\begin{tabular}{|l|l|} 
2"x4" Wood Frame + ext. insulation (4") \\
U VALUE : $0.174 \mathrm{~W} / \mathrm{m}^{2} \mathrm{~K}$
\end{tabular}

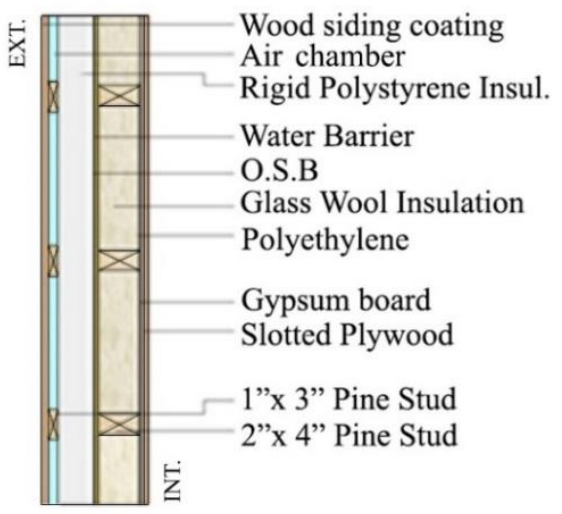

(PLAN VIEW)

S6

Double Frame + int. insulation (4")

U VALUE : $0.144 \mathrm{~W} / \mathrm{m}^{2} \mathrm{~K}$

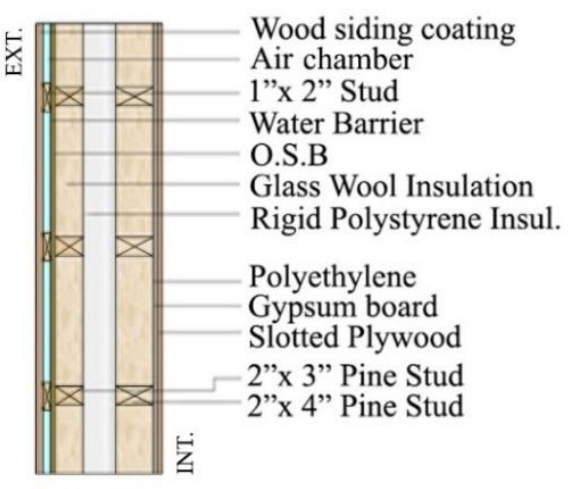

(PLAN VIEW) 


\section{Therm software settings}

To make the thermal flow evaluations and considering the lack of a Chilean standard, the simplified method suggested by the software was used for the boundary conditions (Lawrence Berkeley National Laboratory, 2013). This set the indoor and outdoor temperature of the detail at $20^{\circ} \mathrm{C}$ and $0^{\circ} \mathrm{C}$ respectively. In addition, using these values can help when comparing the results with other envelope studies, such as the one presented by Muñoz \& Bobadilla (2012), which use these values as reference.

The materials used for the thermal flow studies and their respective thermal conductivity are those which are found described in Chilean Standard NCh.853 (Instituto Nacional de Normalización, 2007). Likewise, the film coefficient values entered into the software represent the opposite of the indoor superficial resistance (Rsi) and outdoor superficial resistance (Rse) mentioned in NCh.853 (1/Rsi and 1/Rse). Based on this, when there are no air chambers in an element with horizontal heat flow, the indoor film coefficient is $1 / 0.12$ and the outdoor film coefficient is $1 / 0.05$. If there is an air chamber, both coefficients will be $1 / 0.12$. When the heat flows vertically, ascending through a horizontal element (or with a slope that is less than or equal to $60^{\circ}$ ), the film coefficient values will be $1 / 0.09$ for indoors and $1 / 0.05$ for outdoors. When the flow descends, the coefficient will be $1 / 0.17$ for indoors and $1 / 0.05$ for outdoors.

For the wall - roof joints analysis, a pitched wooden truss roof solution with internal glass wool was used. This roof complies with the $\mathrm{U}$ value of $0.25 \mathrm{~W} / \mathrm{m}^{2} \mathrm{~K}$ required for roofs by the Chilean standard O.G.U.C (Ministerio de Vivienda y Urbanismo, 2017). For the Wall - Floor joints, a common non-ventilated concrete floor solution (with concrete foundation) was used.

\section{Influence of the structural thermal bridges on the envelope}

Once all the parameters are set in the Therm software, the thermal flow for each joint of the envelope elements in the six selected solutions (plus the base solution) is simulated. Figure 3 shows the thermal flow simulation made for three of the solutions, the base solution, Solution 3 (S3) and Solution 5 (S5). Table 1 shows the linear thermal transmittance values obtained. It can be seen how each solution has different qualities which give them some type of advantage. Despite the simple 2" $\times 4$ " wood-frame solution (S1) being the one with the highest $U$ value, it has a clear reduction in the thermal bridge magnitude versus the base solution. With regard to the wall-roof joints, the double wood frame solutions (S5 and S6) have the lowest linear thermal transmittances; however, the 2" x 4" wood frame solutions with external insulation (S3 and S4) are the ones with lower wall-mezzanine and wall-wall joints thermal bridges. In the case of the wall-floor joints, both the double wood frame solutions (S5 and S6) and the wood frame with external insulation solutions (S3 and S4) have an appreciably lower linear transmittance, while finally for the case of the wall-frame joints, all the solutions analyzed have lower values than the base case.

Table 1. Thermal flow simulation results. Source: Own preparation.

Linear thermal transmittance of the thermal bridge $(\Psi)$

(W/mK)

\begin{tabular}{lccccc}
\hline Wall type & Wall-roof & Wall-wall & Wall-frame & Wall-mezzanine & Wall-floor \\
Base & 0.46 & 0.167 & 0.039 & 0.094 & 0.696 \\
S1 & 0.218 & 0.084 & 0.013 & 0.09 & 0.588 \\
S2 & 0.159 & 0.062 & 0.011 & 0.083 & 0.537 \\
& 0.088 & 0.032 & 0.015 & 0.033 & 0.382 \\
S4 & 0.067 & 0.029 & 0.012 & 0.028 & 0.377 \\
S5 & 0.022 & 0.074 & 0.013 & 0.068 & 0.041 \\
S6 & 0.019 & 0.066 & 0.009 & 0.055 & 0.038 \\
\hline
\end{tabular}


Figure 3. Thermal flow study comparison between Base solution, S3 and S5. Source: Own preparation using Therm software.
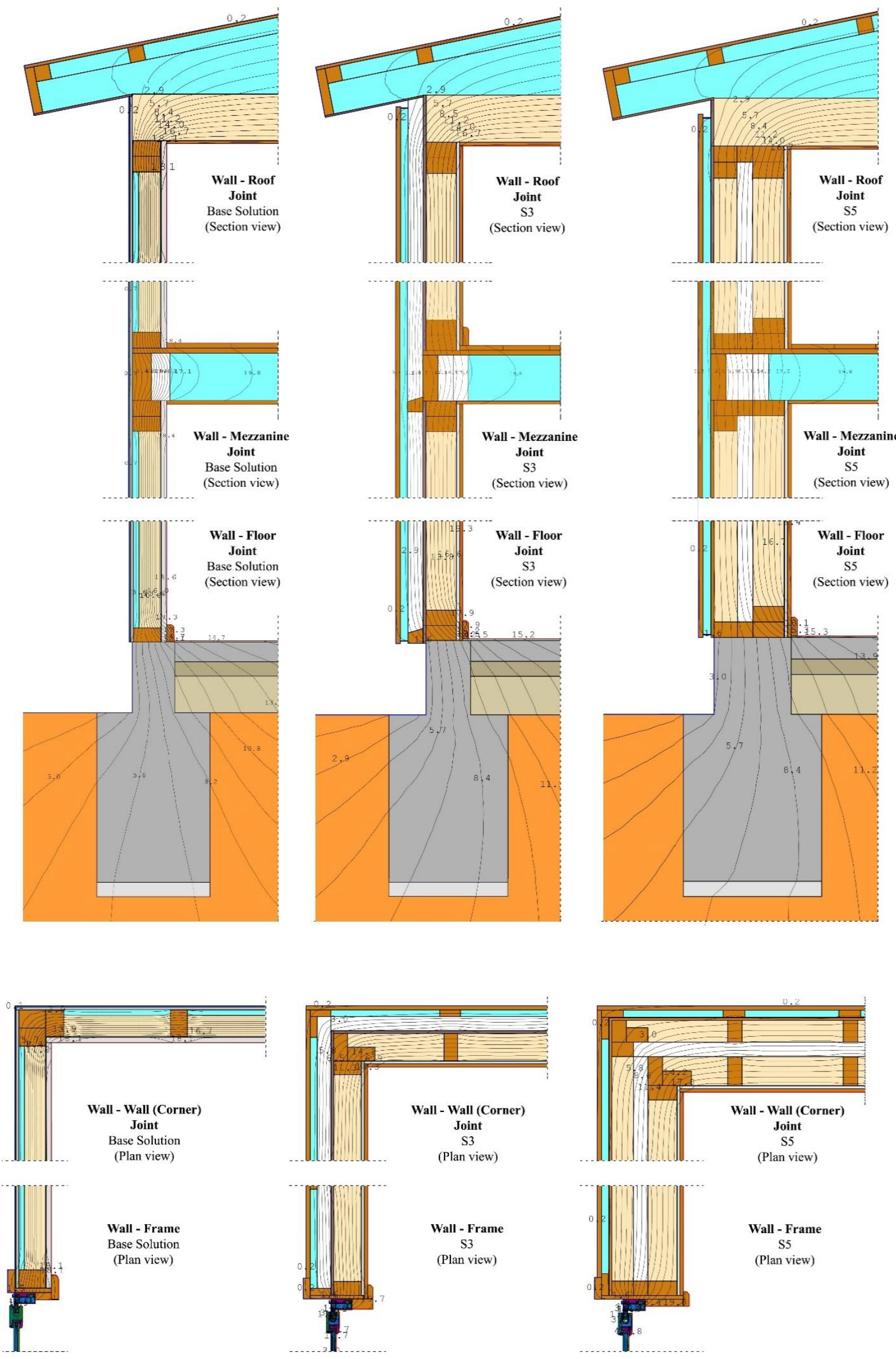

Wall - Frame

(Plan view) 


\section{Stage (d): Dynamic energy simulations}

Dynamic energy simulations were made for the energy demand studies using the DesignBuilder software, which uses Energy Plus as its simulation engine. The goal of this stage is to quantify the annual heating energy demand of an establishment in the southern area of Chile, incorporating the different construction solutions selected, to thus be able to measure the change generated at an energy level by their incorporation into envelopes.

To model the geometry in the software, so the results obtained are applicable in a large number of establishments, a classroom wing at the Liceo Austral Lord Cochrane School, located in Cochrane was chosen as a representative school from the South. This was done after making a study of Southern educational establishment typologies which concluded that a great number of these have volumetric distribution around a central area which generally has a yard or outdoor pitch. Most of these establishments have large rectangular wings with classrooms that are approximately $54 \mathrm{~m}^{2}$ in size each, spread along the wing's entire length on both sides. They also have windows placed on the classroom's extended face with a surface area that occupies between $20 \%$ to $23 \%$ of the classroom's surface and pronounced pitched roofs made of wooden structural trusses. In addition to incorporating all the characteristics mentioned, the establishment chosen is also mentioned in the document Nuevos espacios educativos 2010-2013 (New educational spaces 2010-2013) as a model establishment for the area (Ministerio de Educación, 2013).

\section{Parameters set for the energy simulation}

The climate of the city of Punta Arenas (EPW weather data) is used for the dynamic simulation as this is the city with the largest population and most educational establishments in the area. It is also the regional capital which has the most extreme weather conditions, ones which are very similar to several Canadian cities. The classroom wing used for the simulations (Figure 4) has a total built surface of $555 \mathrm{~m}^{2}$ distributed in two levels with nine $54 \mathrm{~m}^{2}$ classrooms, 4 toilets, 3 storage rooms and 1 office. This wing has large picture windows on its two longest faces and as such it is affected by two orientations, north and south; however, the main face where most of the classrooms are located, is oriented to the south because, according to the results that the GEEEduc guide shows for the " $8 \mathrm{SE}$ " climate zone, this is the orientation where the influence of the envelope can be seen most clearly (CITEC UBB, 2012a).

For the construction settings, the six envelope solutions (and the base solution) were utilized separately as External Wall in different simulations. Regarding the window settings, as well as in the Therm software details, double glazing windows with internal air gap are used with a $U$ value of $1,901 \mathrm{Wm}^{2} \mathrm{~K}$ and PVC frames.

The $n 50$ value of 4.0 air changes per hour at $50 \mathrm{~Pa}$ (ach), is set as the envelope's airtightness as there are studies which suggest this as an acceptable value for the entire area comprising the southern Chilean territory (between the cities of Coyhaique and Puerto Williams) (Bobadilla et al., 2014).

With regard to the Comfort ranges, the only legislation which sets a minimum comfort temperature in Chile for inside an educational establishment is the DS.548 (Ministerio de Educación, 2012). This sets a minimum temperature inside a classroom at $12^{\circ} \mathrm{C}$; however, this requirement is only applicable for certain areas of the country and the standards set out are low (CITEC UBB, 2012a). Other countries which have defined comfort ranges for schools indicate the following: Peru $18^{\circ} \mathrm{C}-25^{\circ} \mathrm{C}$ (Ministerio de Educación, 2006), England $18^{\circ} \mathrm{C}-24^{\circ} \mathrm{C}$ (Department for Education and Skills., 2003), and the USA $17^{\circ} \mathrm{C}-24^{\circ} \mathrm{C}$ (A.S.H.R.A.E, 2004). For the purposes of this study, the comfort values set out by England are used, as these form one of the most complete standards. They do not just set stable thermal comfort parameters for educational spaces (from $18^{\circ} \mathrm{C}$ to $24^{\circ} \mathrm{C}$ ), but rather they also set additional values, for example, the establishment must not exceed $28^{\circ} \mathrm{C}$ for more than $80 \mathrm{hrs}$. in one year.

A general suspended lighting system is used for the wing's artificial lighting, with an efficiency limit value of $5 \mathrm{~W} / \mathrm{m}^{2}$ for every 100 lux. A fan coil unit type cooling and heating system is used for air-conditioning, with a performance coefficient (Heating and cooling system seasonal CoP) equal to 1.0. The natural ventilation is left activated with a standard range of $5 \mathrm{ac} / \mathrm{h}$.

With regard to the occupation, the values per site (person $/ \mathrm{m}^{2}$ ) set out in the Design criteria for new educational spaces document (Ministerio de Educación, 2014) are used along with a metabolic factor, recommended by the software, of 0.9. The establishment's spaces are used from Monday to Friday, from $7 \mathrm{am}$ to $6 \mathrm{pm}$, from February to December, with an occupation decreasing by $80 \%$ from $12 \mathrm{pm}$. to $1 \mathrm{pm}$. because of the duration of the school day change. The occupation of the establishment during the last week of July and the first week of August drops by $85 \%$ as, due to Winter break, only a few activities take place there. 


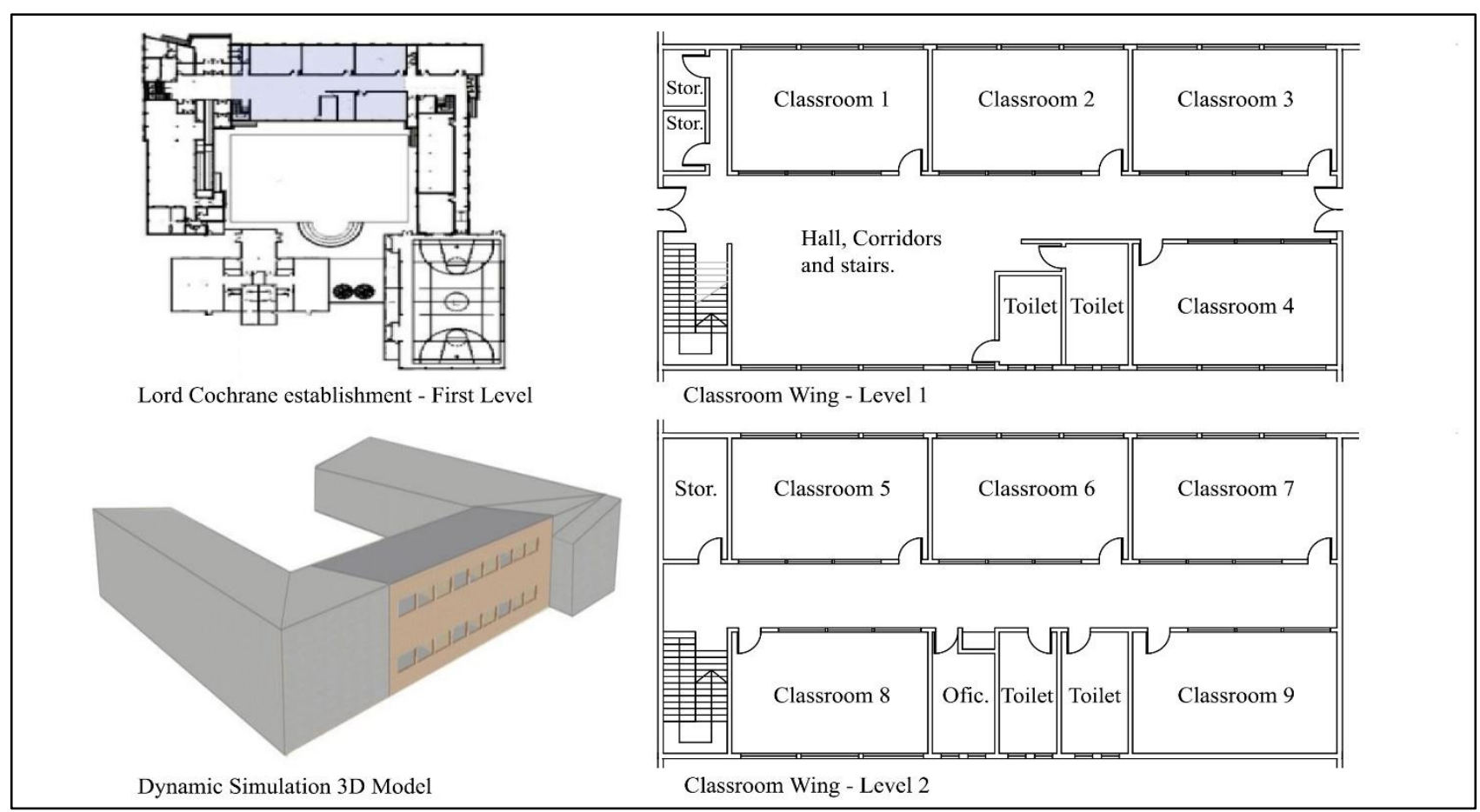

DesignBuilder 5.0.3.007 allows incorporating two types of thermal bridges in the 3D model: First, those generated by the inside structure of the wall's linear section which are incorporated as a percentage. In this case, $14 \%$ for the wooden structural section and $86 \%$ for the insulated section. The second value that can be incorporated is the linear thermal transmittances $(\Psi)$. At this point, all the values obtained in the studies made with Therm (Table 1 ) are incorporated.

\section{Results: Envelope solutions thermal performance}

In Figure 5, the monthly heating demand results of the building incorporating the different solutions are compared. A great difference between the demand generated incorporating the base solution and all the wood-frame solutions evaluated can be appreciated. During the most critical months, June and July, the difference between the base demand and the one generated by the simple $2 " x 4$ " wood-frame solution (S1) is $34 \%$. This difference is $51 \%$ with the double wood-frame wall with 4" internal insulation (S6), thus being the envelope solution that generates the greatest reduction in the demand. It can be seen that the reduction produced by the 2"x 4" wood-frame with 2" external insulation (S3) and the simple $2 " \times 6 "$ wood-frame wall (S2) is practically the same.

When comparing the energy demand results generated by the simple 2 "x 4 " wood-frame wall and the 2 "x 4 " woodframe with 2" continuous insulation (S1 and S3), it can be seen that the difference is considerable, as such it can be inferred that the incorporation of the 2 " continuous external insulation generates a reduction of almost $10 \%$ of the heating demand during the coldest months. However, when comparing the demand results produced by the double wood frame solutions with 2" and 4" internal insulation (S5 and S6) and the 2"x 4" wood frame solutions with 2" and 4" external insulation (S3 and S4), it can be seen that the increase of the continuous insulation from 2" to 4" in thickness does not produce great differences in the demand (Less than $3 \%$ for the critical months). 
Figure 5. Monthly heating demand of the evaluated vertical envelope solutions. Source: Own preparation using data provided by DesignBuilder.

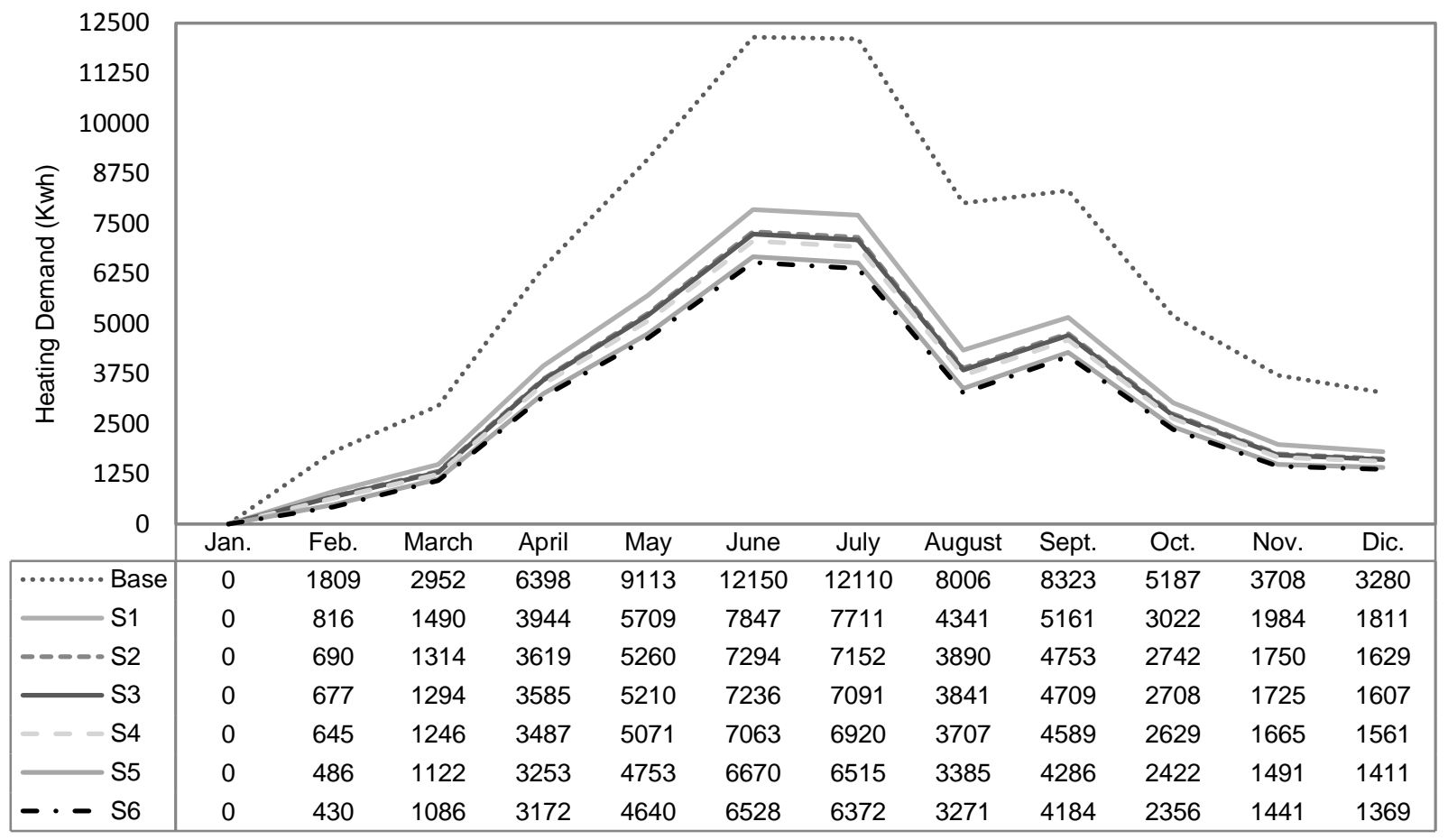

When performing an hourly analysis on a typical winter week from July $1^{\text {st }}$ to July $7^{\text {th }}$ (Figure 6 ), it can be observed that the greates difference in the heating demand generated by the building using the different solutions is produced between 7:00 to 9:00 am. as these are the hours during which the establishment is exposed to lower external temperatures under higher occupation conditions. As expected, the base solution presents the higher demand by far with an hourly heating demand of 50 to $60 \mathrm{Kwh}$ during the first two hours of the morning, the solution 1 (S1) makes it possible to reduce this demand by approximately $42 \%$, while the double Wood-frame solutions (S5 and S6) achieve a reduction of approximately $55 \%$ of the heating demand during week days.

With the incorporation of envelopes S5 and S6 (Double Wood-frame) the heating demand is zero between 12:00 and 13:00 hours, however this is also related to the change in the school day morning classes to afternoon classes;

On the weekend (July $6^{\text {th }}$ and $7^{\text {th }}$ ), it is also possible to observe a notorious difference between the different selected solutions and the base solution, however as the occupancy of the establishment is reduced on weekends, the reduction of demand is lower.

Figure 6. Hourly heating demand of the evaluated vertical envelope solutions on a winter typical week (01 Jul. - 07 Jul.). Source: Own preparation using data provided by DesignBuilder.

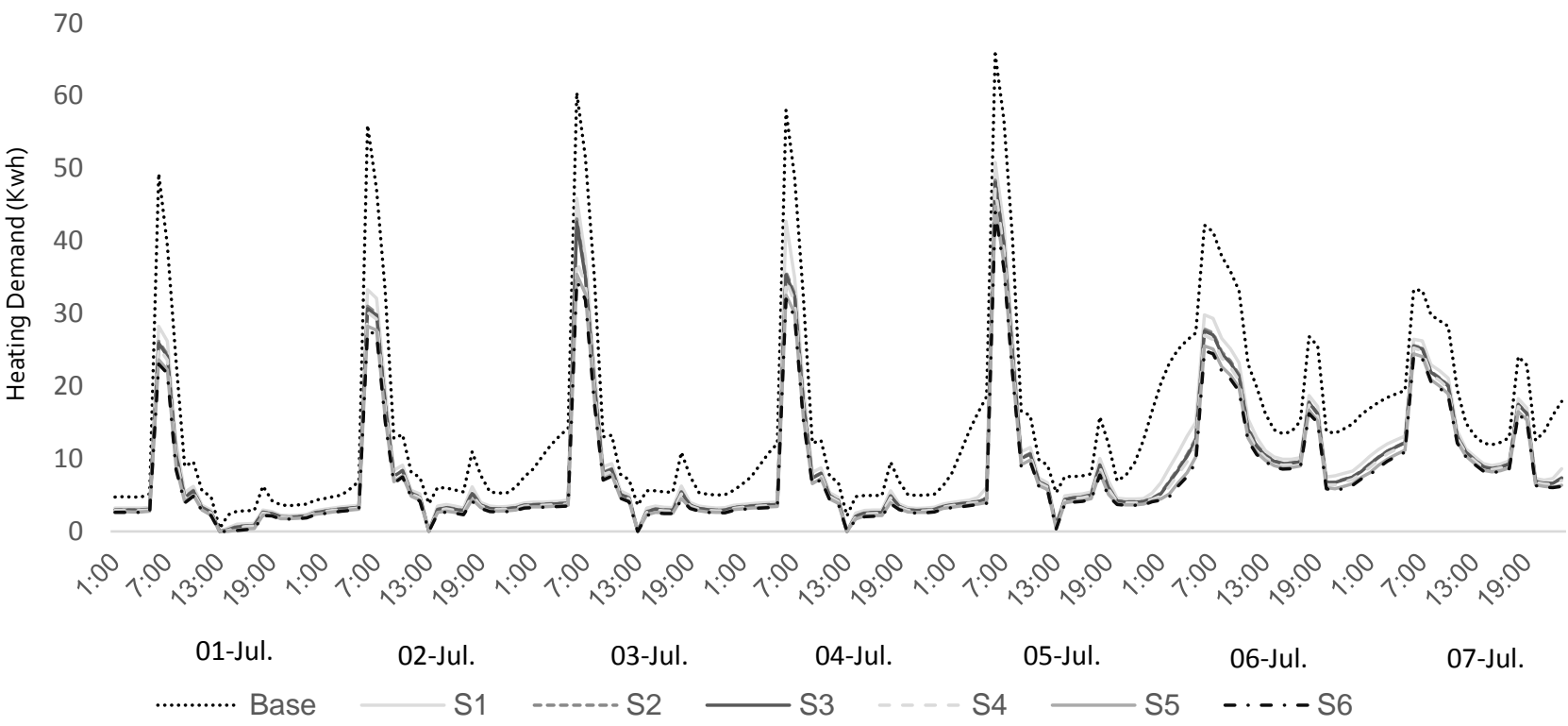


Upon comparing the $U$ value of the envelopes analyzed with the annual heating demand of the establishment incorporating the analyzed solutions (Figure 7), it is seen that the annual demand of an educational establishment $\left(\mathrm{Kwh} / \mathrm{m}^{2}\right.$ Year) is directly related with the $U$ value of the vertical envelope solution used. As the $U$ value decreases, so does the heating demand. However, as the wall's resistance increases, the energy savings generated will be lower until reaching a point where the reduction in the demand will not be significant. It should also be considered that although the cooling demand does not represent high values due to cold weather conditions, it increases as the $U$ value of the envelope decreases.

Figure 7. Comparison between annual energy demand and $U$ value of each solution. Source: Own preparation using data provided by DesignBuilder

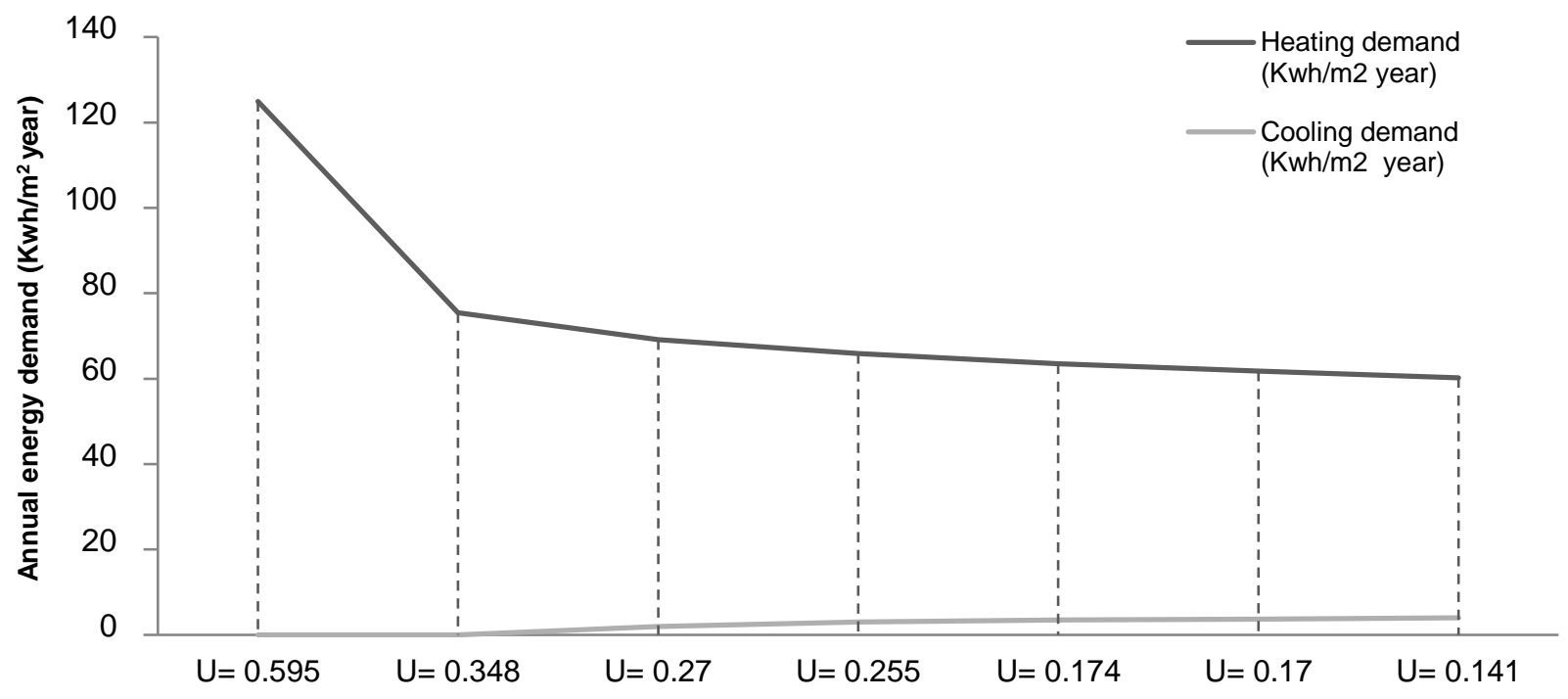

Thermal transmittance of the solutions analyzed

Dynamic simulation using Energy Plus as the engine is a validated tool for predicting the energy performance of a building (Witte, Henninger, \& Glazer, 2001). However, several building envelope performance studies consider thermal bridges only as a percentage within the total area of the vertical envelope. By doing this, the dynamic simulation software adjusts the ammount of insulation in the vertical envelope without taking into consideration the thermal bridges produced in the structural joints.

When previously calculating linear thermal transmittance of the solution joints and incorporating them into the dynamic simulations, the energy demand results consider the heat loss produced in the joints of each of the envelope elements and that is why, although the methodology utilized requires more time, it provides results much closer to reality. As the study made by Ge, Hua \& Baba, Fuad (2017) shows, considering the thermal bridges of the joints in a building modifies the annual space heating demand results in a considerable percentage.

This study shows the thermal and energy efficiency which can be achieved with the different wood-frame solutions analyzed, when applied on vertical envelopes of establishments located in cold climate conditions. It demonstrates that considerable benefits can be generated, not only at an energy level, using wood-frame construction systems, whose incorporation does not require specialized labor, but also in a user's health level by reducing the use of heating systems that release great amounts of humidity and contaminants into the environment.

The studies carried out, demonstrate that all the vertical envelope solutions assessed present noticeable improvements in the heating energy demand. On incorporating any of the six solutions evaluated for the envelope, the thermal performance of the educational establishments located in the southern area of Chile, evidences considerable improvements of up to $51 \%$ during the coldest months of the year.

The continuous outdoor insulation, as seen in the 2"x4" wood-frame solutions with 2 " and 4" thick external insulation (S3 and S4), greatly improves the thermal performance of a building since it prevents much of the heat losses produced 
by the thermal bridges generated in the joints of some elements like the corners and the mezzanine with the walls. The results also show that increasing the thickness of the external insulation from 2" to 4" does not considerably increase the thermal performance and could end up being a poor investment. However, to check this, studies must be made which compare the incorporation cost with the energy and monetary benefits that are generated.

The energy demand studies show that the thermal performance of the simple 2"x6" wood-frame solution (S2) is quite similar to the 2"x4" wood-frame solutions with outdoor 2" and 4" insulation (S3 and S4); therefore, when it comes to choosing one of these for a building envelope, this must be done considering other external factors such as, for example, the availability of the material needed.

The solutions which have the lowest thermal transmittance $(U)$ and linear thermal transmittance $(\Psi)$ values are the ones that have a better performance at a heating demand reduction level, which infers that these factors have a direct impact, and are key considerations when it comes to choosing a vertical envelope.

It is expected that the benefits generated by the incorporation of the evaluated solutions extend beyond educational establishments and be generated in other types of buildings, even in residential buildings, as long as these are located in places where climates are similar to those of the Canadian climate zone "7a" and Chilean climate zone "8 SE".

The results achieved make it possible to promote wood as an ideal construction material to meet the goals of reducing energy demand and increasing building efficiency, as set out in the non-renewable energy reduction plan, Energía 2050 (Energy 2050) (Comité Consultivo de Energía, 2016). Notwithstanding the above, in order to achieve this, it is recommended to develop further studies taking into consideration not only the Chilean southern zone climate but also other different climates.

References

A.S.H.R.A.E. (2001). Standard 62-2001. Ventilation for acceptable indoor air quality.

A.S.H.R.A.E. (2004). Standard 55-2004. Thermal environmental conditions for human occupancy, 2004. https://doi.org/10.1007/s11926-011-0203-9

Adonis, M., \& Gil, L. (2001). Indoor air pollution in a zone of extreme poverty of metropolitan Santiago, Chile. Indoor and Built Environment, 7(1027), 138-146. https://doi.org/10.1177/1420326X0101000304

Armijo, G., Whitman, C., \& Casals, R. (2011). Post-Occupancy Evaluation of State Schools in 5 Climatic Zones of Chile. Gazi University Journal of Science, $24(2), 365-374$.

Beggs, P. J. (2010). Adaptation to impacts of climate change on aeroallergens and allergic respiratory diseases. International Journal of Environmental Research and Public Health, 7(8), 3006-3021. https://doi.org/10.3390/ijerph7083006

Bobadilla, A., Arriagada, R., Figueroa, R., Muñoz, C., Espinoza, R., Díaz, M., \& Fookes, J. (2014). Manual de hermeticidad al aire de edificaciones.

Burrows, J. (2006). Canadian wood-frame house construction. Available online at: http://chbanl.ca/wp-content/uploads/CMHC-Canadian-WoodFrame-House-Construction.pdf

CITEC UBB. (2012a). Guia Eficiencia Energética para Establecimientos Educacionales. https://issuu.com/citecubb/docs/guia-geeeduc-baja

CITEC UBB. (2012b). TDRe: Términos de Referencia Estandarizados con Parámetros de Eficiencia Energética y Confort Ambiental, para Licitaciones de Diseño y Obra de la Dirección de Arquitetura, Según Zonas Geográficas del País y Según Tipología de Edificios. Retrieved from http://arquitectura.mop.cl/eficienciaenergetica/Paginas/default.aspx

Comité Consultivo de Energía. (2016). ENERGÍA 2050 Política Energética de Chile. http://www.energia.gob.cl/sites/default/files/energia_2050__politica_energetica_de_chile.pdf

Department for Education and Skills. (2003). Building Bullentin 87: Guidelines for Environmental Design in Schools (Vol. 1).

Finch, G., Wang, J., \& Ricketts, D. (n.d.). Guide for Designing Energy-Efficient Building Enclosures for Wood-Frame Multi-Unit Residential Buildings in Marine to Cold Climate Zones in North America. Vancouver. Retrieved from http://rdh.com/wp-content/uploads/2014/07/Guide-for-DesigningEnergy-Efficient-Building-Enclosures.pdf

Ge, H., \& Baba, F. (2017). Effect of dynamic modeling of thermal bridges on the energy performance of residential buildings with high thermal mass for cold climates. Sustainable Cities and Society, 34(June), 250-263. https://doi.org/10.1016/j.scs.2017.06.016

Høibø, O., Hansen, E., \& Nybakk, E. (2015). Building material preferences with a focus on wood in urban housing: durability and environmental impacts. Canadian Journal of Forest Research, 45(11), 1617-1627. https://doi.org/10.1139/cjfr-2015-0123

Instituto Nacional de Normalización. (2007). Norma Chilena 853: Acondicionamiento térmico - Envolvente térmica de edificios - Cálculo de resistencias y transmitancias térmicas. Santiago. https://doi.org/10.1017/CBO9781107415324.004

Instituto Nacional de Normalización. (2008). Norma Chilena 1079: Arquitectura y Construcción - Zonificación climático habitacional para Chile y recomendaciones para el diseño arquitectónico. Santiago. 
International Organization for Standardization. (2017). 10211 - Thermal bridges in building construction-Heat flows and surface temperatures - Part 1: General calculation methods (Vol. 2017). Brussels.

Ko, M., Gosti, T., \& Kristl, Ž. (2018). Influence of architectural building envelope characteristics on energy performance in Central European climatic conditions, 15(August 2017), 278-288. https://doi.org/10.1016/j.jobe.2017.11.023

Kosny, J., Asiz, A., Smith, I., Shrestha, S., \& Fallahi, A. (2014). A review of high R-value wood framed and composite wood wall technologies using advanced insulation techniques. Energy and Buildings, 72, 441-456. https://doi.org/10.1016/j.enbuild.2014.01.004

Lawrence Berkeley National Laboratory. (2013). THERM 6.3 / WINDOW 6.3 NFRC Simulation Manual.

Mazzei, P., Minichiello, F., \& Palma, D. (2005). HVAC dehumidification systems for thermal comfort: A critical review. Applied Thermal Engineering, 25(5-6), 677-707. https://doi.org/10.1016/j.applthermaleng.2004.07.014

Méndez, T., Capozzoli, A., Cascone, Y., \& Sassone, M. (2015). The early design stage of a building envelope : Multi-objective search through heating , cooling and lighting energy performance analysis, 154, 577-591. https://doi.org/10.1016/j.apenergy.2015.04.090

Ministerio de Educación. (2006). Criterios normativos para el diseño de locales de educación básica regular niveles de inicial, primaria, secundaria y básica especial. Lima, Perú.

Ministerio de Educación. (2012). Decreto 548. Santiago, Chile. http://www.comunidadescolar.cl/marco_legal/Decretos/Decreto548.pdf

Ministerio de Educación. (2013). Nuevos espacios educativos 2010-2013. Santiago, Chile. https://infraestructuraescolar.mineduc.cl/estudios-ypublicaciones/nuevos-espacios-educativos-1999-2001-2003-2005-2007-2010-2013/

Ministerio de Educación. (2014). Criterios de diseño para los nuevos espacios educativos: En el marco del fortalecimiento de la educación pública. Santiago, Chile.

Ministerio de Vivienda y Urbanismo. (2014). Listado Oficial de Soluciones Constructivas para Acondicionamiento Térmico del Ministerio de Vivienda y Urbanismo (Vol. 1434). Santiago, Chile.

Ministerio de Vivienda y Urbanismo. (2017). Ordenanza General de Urbanismo y Construcciones.

Muñoz, C., \& Bobadilla, A. (2012). Simulación y evaluación de puentes térmicos soluciones constructivas típicas aprobadas por la norma térmica para elementos verticales en estructura de madera y metálicos en la zona 4 simulaciones con therm y usai y evaluación con método de cámara térmica. Revista de La Construccion, 11(2), 92-111. https://doi.org/10.4067/S0718-915X2012000200009

National Research Council of Canada. (2011). National Energy Code for Buildings. Ottawa.

National Research Council of Canada. (2012). National building code of Canada. Ottawa. https://doi.org/10.1111/jnu.12100

Nawawi, A., \& Khalil, N. (2008). Post-occupancy evaluation correlated with building occupants' satisfaction: An approach to performance evaluation of government and public buildings. Journal of Building Appraisal, 4(2), 59-69. https://doi.org/10.1057/jba.2008.22

Okolie, K. C. (2011). Performance evaluation of buildings in Educational Institutions: A case of Universities in South-East Nigeria.

Raizenne, M., Dales, R., \& Burnett, R. (1998). Air Pollution Exposures and Children 's Air pollution exposures and children's health. Canadian Journal of Public Health, 89(June 1998), 43-48.

Rodriguez-ubinas, E., Montero, C., Porteros, M., \& Vega, S. (2014). Passive design strategies and performance of Net Energy Plus Houses, 83, 10-22. https://doi.org/10.1016/j.enbuild.2014.03.074

Rubeis, T., Nardi, I., Ambrosini, D., \& Paoletti, D. (2018). Is a selfsufficient building energy efficient? Lesson learned from a case study in Mediterranean climate. Applied Energy, 218(March), 131-145. https://doi.org/10.1016/j.apenergy.2018.02.166

Strobel, K., Nyrud, A., \& Bysheim, K. (2017). Interior wood use: linking user perceptions to physical properties. Scandinavian Journal of Forest Research, 7581(March), 1-9. https://doi.org/10.1080/02827581.2017.1287299

Tadeu, A., Simões, I., Simões, N., \& Prata, J. (2011). Simulation of dynamic linear thermal bridges using a boundary element method model in the frequency domain. Energy and Buildings, 43(12), 3685-3695. https://doi.org/10.1016/j.enbuild.2011.10.001

Tookaloo, A., \& Smith, R. (2015). Post Occupancy Evaluation in Higher Education. Procedia Engineering, 118, 515-521. https://doi.org/10.1016/j.proeng.2015.08.470

Torres-rivas, A., Palumbo, M., Haddad, A., Cabeza, L., \& Jiménez, L. (2018). Multi-objective optimisation of bio-based thermal insulation materials in building envelopes considering condensation risk. Applied Energy, 224(April), 602-614. https://doi.org/10.1016/j.apenergy.2018.04.079

Trebilcock, M., Soto, J., Figueroa, R., \& Piderit, B. (2016). Metodología para el diseño de edificios educacionales confortables y resilientes. Revista AUS, (20), 70-76. https://doi.org/10.4206/aus.2016.n20-11

Witte, M., Henninger, R., \& Glazer, J. (2001). Testing and validating of a new building energy simulation program, 353-360. 